\title{
Calcified Chronic Subdural Hematoma
}

ISSN: 2637-7748

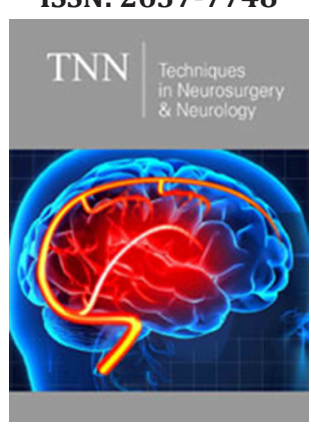

*Corresponding author: Gómez Fortty María delos Angeles and González Echeverría Kléber Eduardo,

Neurosurgery department, San francisco clinic hospital, Ecuador

Esqueda Liquiano Mauricio Armando, Head of the department of neurosurgery naval medical center of mexico

Submission: 海 August 13, 2020

Published: 比 October 09, 2020

Volume 3 - Issue 4

How to cite this article: Gomez fortty mariadelos angeles, Gonzalez EKB, Esqueda LMA. Calcified Chronic Subdural Hematoma. Tech Neurosurg Neurol. 3(4). TNN. 000566. 2020

DOI: 10.31031/TNN.2020.03.000566

Copyright@Gomez fortty mariadelos angeles, Gonzalez EKB and Esqueda LMA, This article is distributed under the terms of the Creative Commons Attribution 4.0 International License, which permits unrestricted use and redistribution provided that the original author and source are credited.

\section{Gomez fortty mariadelos angeles ${ }^{1 *}$, Gonzalez EKB ${ }^{1 *}$ and Esqueda LMA ${ }^{2 *}$}

${ }^{1}$ Neurosurgery department, San francisco clinic hospital, Ecuador

${ }^{2} \mathrm{Head}$ of the department of neurosurgery naval medical center of mexico

\section{Medical Image}

\section{Simple skull tomography}

An isodensal image with a wide area of perimeter calcification of left frontoparieccipital extraxial location is observed in a 68-year-old male patient entering with generalized tonicclonic seizure box, hemiplegia on the right side due to a reduction in brain tissue of up to 200 g, with an increase in extra-brain space by 6 to $11 \%$ allowing parenchyma to adapt to the hematoma and that it is stood (Figure 1). The clinical presentation of this pathology is often insidious, with symptoms of decreased level of consciousness, problems in gait due to changes in balance, cognitive dysfunction, memory loss, motor deficit (hemiparesias), headache, or aphasia $[1,2]$. With the presumptive diagnosis, a left parietal craniotomy was performed, through which an encapsulated and calcified lesion was exposed in its entire parietal and visceral face, and that contained a granular substance of dark red color, totally avascular. Radical resection was performed without surgical complications (Figure 2). Final result, successful patient surgical ablation without seizures, regained strength 5/5 in right hemibody, oriented and conscious. It is concluded that chronic subdural hematomas calcification is a rare form of imaging presentation today, known as armoured brain or matryoska brain [3]. Since pseudomembrans are calcified, the chances of brain re-explosion are virtually non- existent [4]; Finally, the decision of the surgery conforms to the clinical or radiological evidence of mass effect. When there is evidence and the need for a craniotomy approach it could be a better option than trepanation in the management of these entities $[4,5]$.

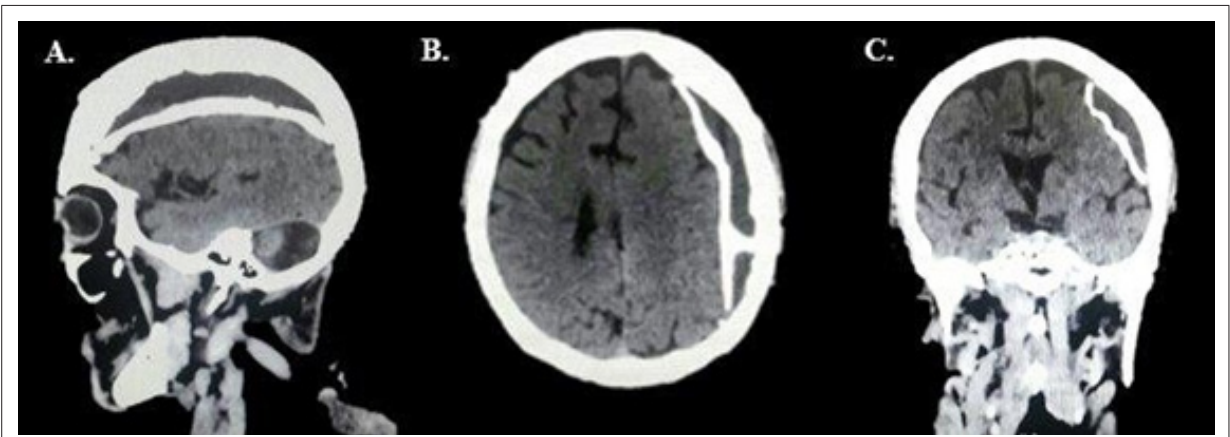

Figure 1: Simple skull tomography: Chronic hemispheric left calcified subdural hematoma in 68-year-old patient. (A) Sagittal cut, is observed a hyperostosis of the bone of the skull vault and chronic subdural hematoma calcified fronto-parieto-occipital of the left side (B) Axial cut, shows mass effect with erasure and compression of ventricular system ipsilateral (C) Coronal cut, samples encapsulated chronic subdural collecting of the left side. 


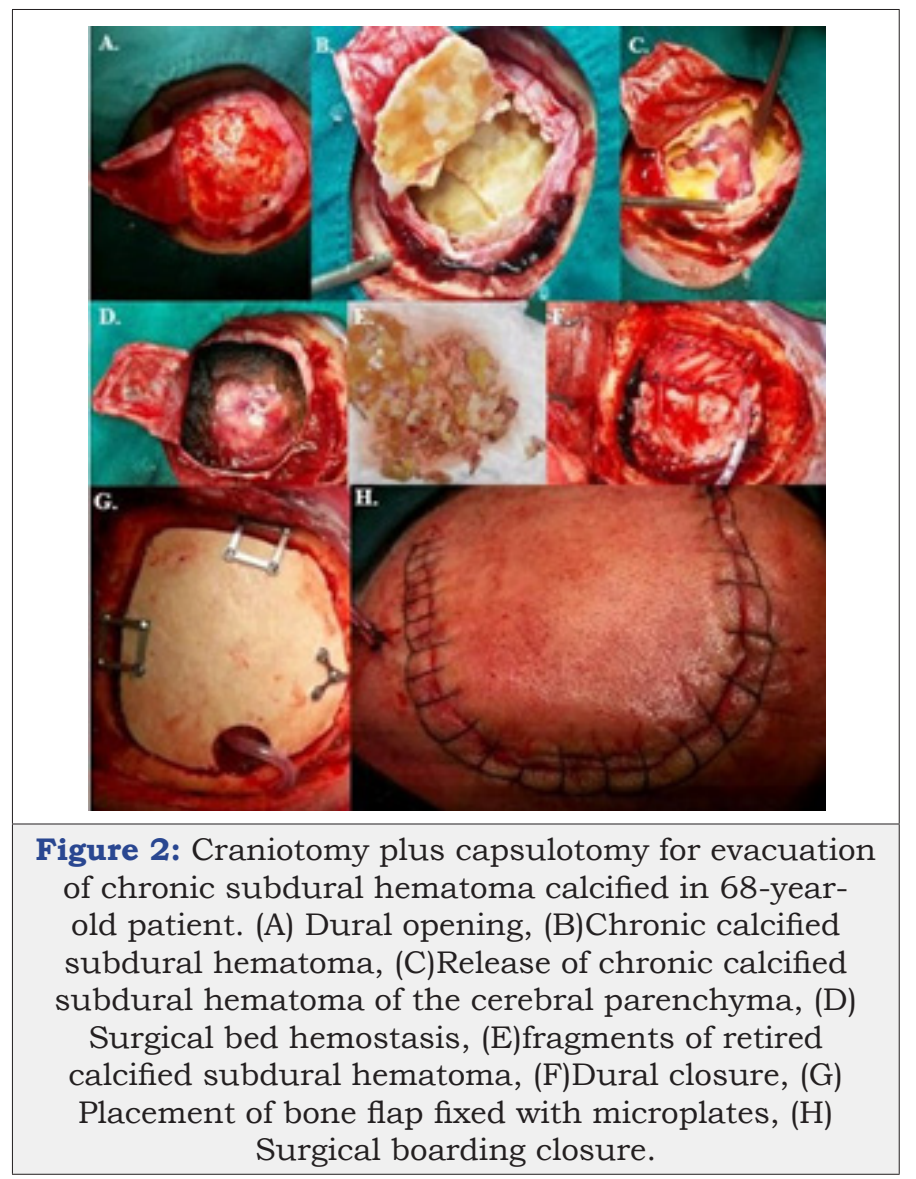

\section{References}

1. Ortega SO, Gil Alfonso M, Bacallao GL, Hechevarría AJ, García DM, et al. (2019) Diagnóstico del hematoma subdural: unproceso de clínica e imágenes dinámico. Rev Med Electrónabril 41(2).

2. Balser D, Farooq S, Mehmood T (2015) Traumatismo craneoencefálico en el adulto mayor. J Neurosurg 1(7).

3. Arán Echabe E, Fieiro Dantes C, Prieto Gonzales Á (2014) Hematoma subdural crónico calcificado: cerebro blindado. Rev Neurolenero 58(9).

4. Santarias T, Kolias A, Hutchinson P (2012) Surgical management of chronic subdural hematoma in adults. Operative Neurosurgical Techniques pp. 1573-1578.

5. García Pallero M, Pulido Rivas P, Pascual Garvi J, G Sola R (2014) Hematomas subdurales cronicos. La arquitectura interna del hematoma como predictor de recurrencia. Rev Neurol octubre 59(7).

For possible submissions Click below: 